
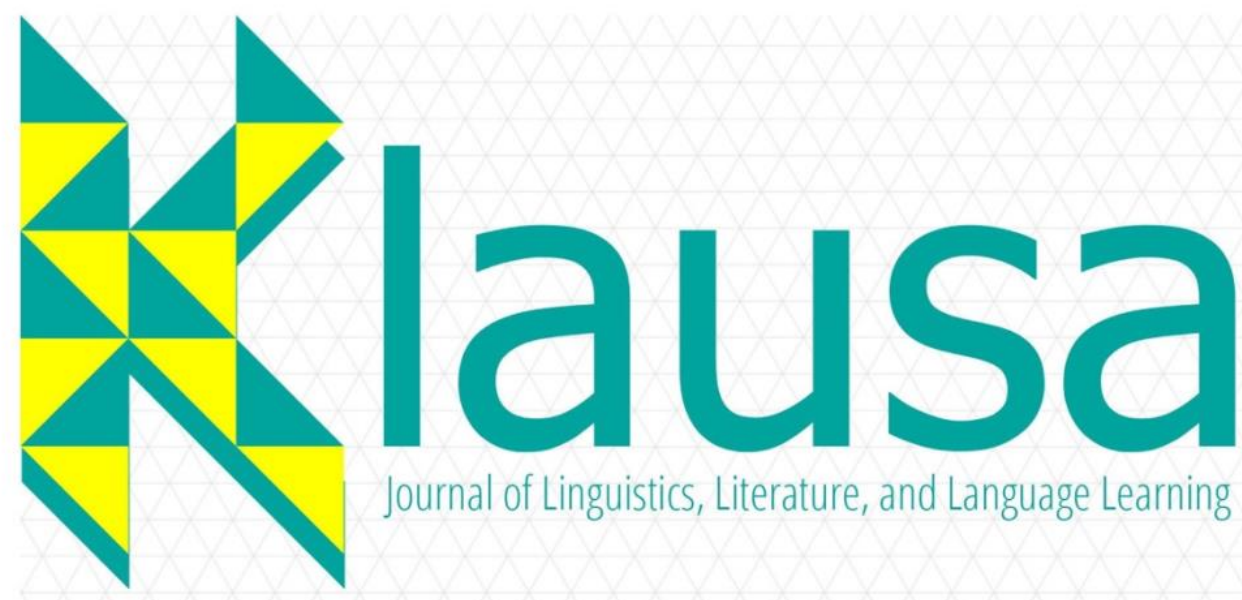

ISSN 2620-9527

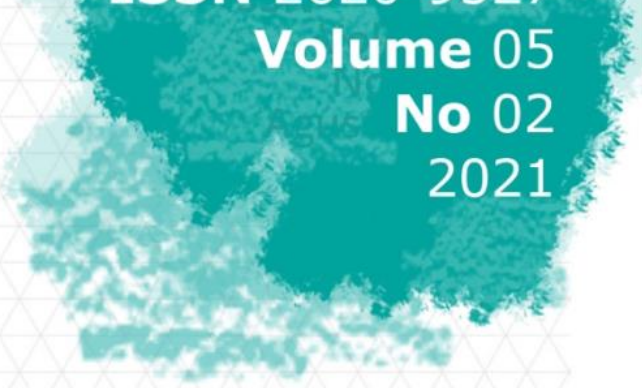

Journal of Linguistics, Literature, and Language Learning

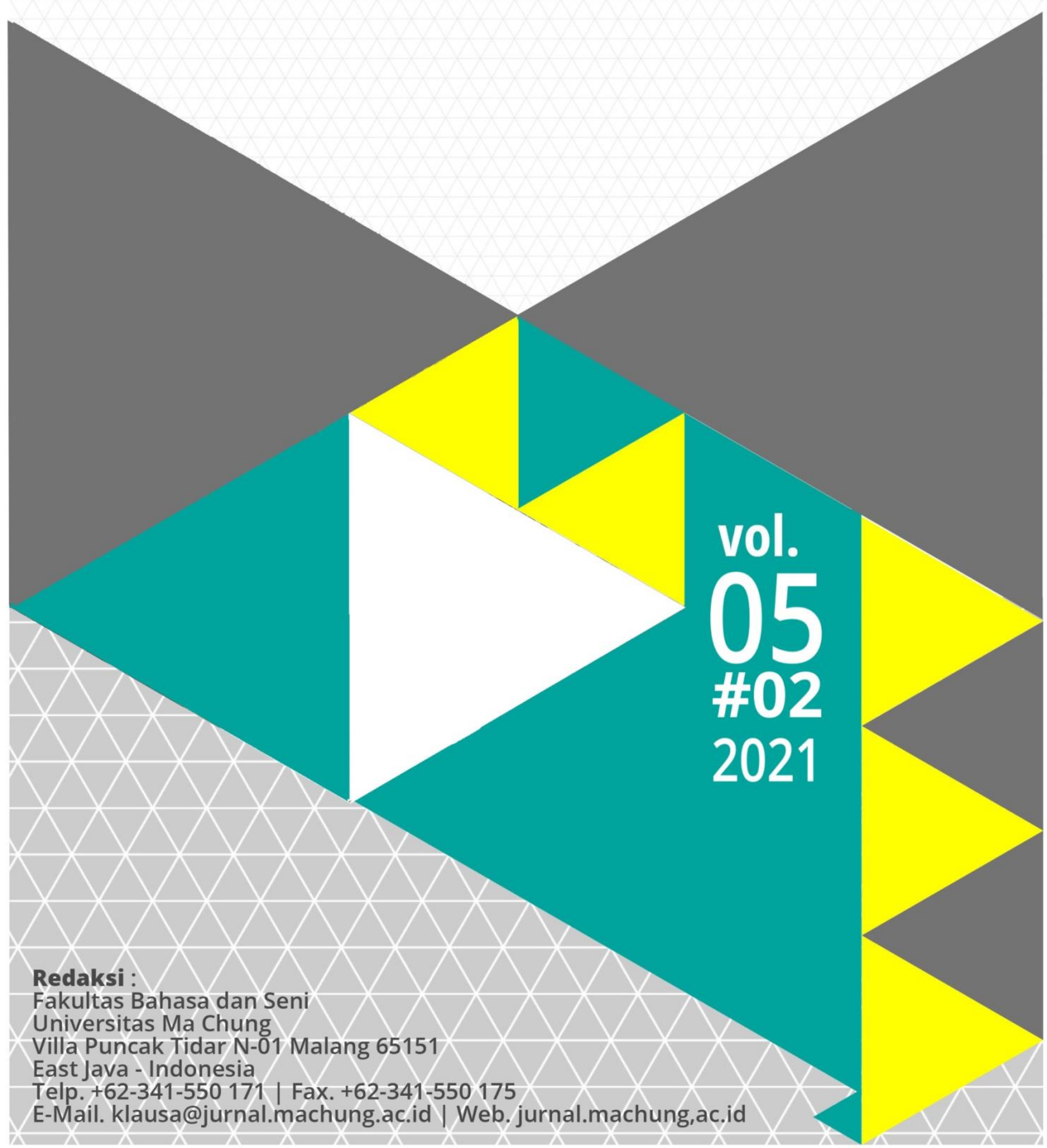


ISSN: $2301-4822(p)$

2620-9527 (e)

DOI:

\section{Kajian Linguistik, Pembelajaran}

Bahasa, dan Sastra

\section{Editorial Team}

Editor-in-Chief:Dr. Daniel Ginting

Journal Manager:Wawan Eko Yulianto, Ph.D.

Editors: Prof. Dr. Patrisius I. Djiwandono

Lilis Lestari Wilujeng, M.Hum.

Reviewers:F.X Dono Sunardi, M.A.

Dhatu Sitaresmi, MTCSOL.

Anggrah Diah Arlinda, MTCSOL.

Yohanna Nirmalasari, S.Pd., M.Pd.

Prof. A. Effendi Kadarisman, Ph.D.

Sisilia Halim, Ph.D.

Dr. Mundi Rahayu

Dr. Ross Wood

Dr. Leticia Araceli Salas Serrano

Publisher: Faculty of Language and Arts

Universitsas Ma Chung

Address: The Faculty of Language and Arts

$$
\begin{aligned}
& \text { Ma Chung University } \\
& \text { Villa Puncak Tidar N-01 (65151) } \\
& \text { Malang, East Java, Indonesia } \\
& \text { Email: jurnal.klausa@machung.ac.id }
\end{aligned}
$$

Frequency: Twice a year 


\section{CONTENTS}

FOREWORD

iii

SOLIDARITY IN THE TOURING NARRATIVE OF S.U.U.A.L (SCOOTER UIN ULUL ALBAB)

MALANG VESPA COMMUNITY: A CRITICAL DISCOURSE ANALYSIS APPROACH

Yunia Dewi Fathmawati ${ }^{1}$

THE ROLE OF PARENTAL GUIDANCE ON VOCABULARY ACHIEVEMENT IN AN INDONESIAN EFL ELEMENTARY EDUCATION SETTING

Christian Edison Bani ${ }^{1}$, Sahiruddin ${ }^{2}$, Ika Nurhayani ${ }^{3}$

MENELAAH POTENSI SASTRA PARIWISATA DI TELAGA SARANGAN

Ardi Wina Saputra ${ }^{1}$, Rustiati ${ }^{2}$

MAKNA KULTURAL DALAM LEKSIKON PERHIASAN PENGANTIN SUNDA PRIANGAN (KAJIAN ETNOLINGUISTIK)

Elda Mnemonica Rosadi ${ }^{1}$, Retty Isnendes ${ }^{2}$, Mahmud Fasya ${ }^{3}$

133

THE ENVIRONMENTAL ASPECTS OF ALEXANDRE DUMAS'

THE COUNT OF MONTE CRISTO

Gusti Ayu Made Suarniti ${ }^{1}$ 


\title{
THE ROLE OF PARENTAL GUIDANCE ON VOCABULARY ACHIEVEMENT IN AN INDONESIAN EFL ELEMENTARY EDUCATION SETTING
}

\author{
Christian Edison Bani ${ }^{1}$, Sahiruddin ${ }^{2}$, Ika Nurhayani ${ }^{3}$ \\ ${ }^{1}$ Universitas Brawijaya, Malang, Indonesia, christianbani@student.ub.ac.id \\ 2 Universitas Brawijaya, Malang, Indonesia, shrdn@ub.ac.id \\ ${ }^{3}$ Universitas Brawijaya, Malang, Indonesia, ikanurhayani@ub.ac.id
}

\begin{abstract}
Parental guidance can be seen as one of the determining factors to assist students in elevating their academic achievement. This study intended to discover the relationship between parental involvement and their children's second language (L2) vocabulary achievement. The data of this study were elicited from teachers' assessment of L2 vocabulary performance for 30 students and questionnaire responses involving 30 parents regarding parental involvement in their children's learning. The study revealed the existence of a significant correlation between parental involvement and students' vocabulary achievement in an Indonesian foreign language learning in an elementary school context. In addition, this study also demonstrated that parents' educational background explained the levels of support involvement which in turn influenced students' vocabulary achievement. The overall findings of this study concerning the pivotal role of parental involvement and their educational background in enhancing their children's achievement in terms of vocabulary learning are also discussed in terms of pedagogical implications.
\end{abstract}

Keywords: parental involvement, vocabulary, foreign language, elementary education

\section{INTRODUCTION}

Regarding the role of English as an international language that is widely acknowledged by most people to exchange ideas or opinions, the English language has become an important subject to be taught in schools. In Indonesia, English is classified as a foreign language which is necessary to master as one of the requirements to have a promising career in the future. Concerning the place of English in Indonesia can be seen 
from the implementation of English instruction for language learners starting from elementary education levels, and it is clarified that the demand for English language learning has elevated drastically (Zein, 2017). Furthermore, the importance of teaching English to young learners has grown quickly since the language has a vital influence in the advanced world as a worldwide language that is utilized for global correspondence, transportation, trade, banking, the travel industry, innovation, strategy, and logical exploration (Brown, 2007). This expresses that by learning English, children have more chances to find more knowledge and comprehension in a foreign language.

English instructions in early education have been broadly recognized by numerous individuals outlining the earlier the better in learning a new language (Birdsong \& Molis, 2001; Wang \& Chang, 2011). It shows that early foreign language instructions are necessary, and students learn most at young ages. Indonesian parents are keen on having their children learn English from the beginning. Subsequently, this expanding interest in learning English seems to have urged more primary schools to incorporate English lessons in their educational plans (Alwasilah, 2013).

It has been debatable that parental involvement seriously affects students' accomplishments in their language learning. It can be a latent or dynamic involvement in supporting students to accomplish a great outcome in the learning progress. Students possess a better academic achievement in their language learning if their parents are steady and dynamic in presenting adequate help in any event when their parents do not communicate in the foreign language (Hosseinpour, 2015). In a huge scope overview study led by Yulianti et al. (2018) which investigated the ramifications of parental involvement on their children's academic performance in Indonesia, it was revealed that Indonesian parents' education and participation at home have a convincing impact (even though proportionately little) on elementary school students' achievement.

Concerning parental role in contributing and fostering their children's achievement in language learning, the effect can be viewed as something significant, and it has been the subject of exact studies for quite a while. For example, Pavalache (2015) researched the connection between parental involvement and the school, the motivation for learning, and achievement. The research was performed on elementary school students going to grades three and four alongside their teachers. The after-effects of such research affirmed the speculation that students' achievement was related to parental involvement and the motivation of the students. This investigation indicates that parental involvement in their children's achievement is essential for forming the motivation to advance well in their language learning.

Taking into account one of the outcomes from the previous studies, this current study plans to investigate the field which has not much been examined. This current study concerns more on the involvement of parents in fostering their children's vocabulary achievement. Advocating with the role of parents in molding and creating motivation and achievement of language learners in their language learning, this study is 
driven by the purpose to reveal more comprehensive insight concerning how parents elevate their children's achievement in learning English as a foreign language. By appreciating the connection between parental involvement in commitment for their children's learning and vocabulary achievement. There will be reasonable ramifications for this study that parental involvement is required by language learners. It is fundamental since little information is known related to the issue of vocabulary achievement as influenced by parental involvement in an Indonesian setting.

By receiving the comparative sort of procedure used by the past investigations, the researcher proposes to limit the areas in the past examinations concentrating just on language learning in general and vocabulary learning in particular. This study assesses the role of parents in improving their children's vocabulary achievement, and elementary students are utilized as the members along with their parents to investigate all the more completely the connection between their involvement and the achievement of the students in their vocabulary learning. In short, this current research endeavors to address the accompanying inquiries: (1) Is there a relationship between parents' involvement and their children's vocabulary achievement? and (2) Is there any significant difference between the level of parents' education and their involvement in their children's vocabulary achievement?

\section{LITERATURE REVIEW}

\section{Vocabulary Learning}

One of the most essential constructs in this study is about vocabulary that can be characterized as an essential component of a language that establishes an unequivocal part in correspondence to pass on a message. Without vocabulary, messages are probably not going to be passed on. As Wilkins (1972) attests, "... while without sentence structure next to no can be passed on, without vocabulary nothing can be passed on." This assertion legitimizes the vital job of vocabulary in language learning as an establishment for students to advance viably.

Learning vocabulary is one of the basic components in learning a second or foreign language and is needed to be figured out how to advance well in different spaces of language learning, in particular: reading, listening, writing, and speaking, which determine students' ability to master a language (Atasheneh, 2015). Aside from sentence structure and pronunciation, vocabulary is one of the language parts needed in learning a language. Vocabulary is deciphered as every one of the words in a specific language (Wehmeier, et al., 2005, p.1707). Vocabulary learning cannot be disregarded and requires more consideration regarding a significant result in language learning. It acquires more noteworthy thought in numerous course readings and language programs (Furneaux, 1999, p.369).

Folse (2004) additionally guarantees that, unexpectedly of L1 vocabulary learning, L2 students should recuperate the structure, the importance, or the use of a word that 
can be obtained by applying various educational exercises. The execution of suitable instructional exercises and procedures can improve the experience in learning a foreign language just as foster students' capabilities. Schmitt (1997) calls attention to vocabulary learning procedures as the perception of practices and systems which are used by students in their language learning. Schmitt additionally concerns more about the way that students need to carry out the prescribed procedures, for example, perceiving the significance of some new words, retaining and applying them in their composed or oral communication.

On the other side, the result of inadequately developed vocabulary can be overwhelming as students who start school with a lack of vocabulary knowledge are slanted to confront a few checks in proficiency that obstructs them to participate in teaching and learning exercises (Hart \& Risley, 1995; Hoff, 2013; National Research Council, 1998). To make students equipped for understanding foreign language vocabulary requires fathomable input which will decide the students' achievement to effectively gain the vocabulary (Barnes et al. 1989; Krashen 1989;). Another viewpoint that is important as well is the utilization of exercises in the classroom setting that do not overpower students' mental state.

\section{Key Concepts of Motivation and Attitudes Toward English Learning}

Motivation is the thing that drives individuals to achieve what they mean to accomplish. The motivation they possess regardless of whether it comes from inside or outside themselves decides the results of language learning. In the investigation of educational psychology, motivation is the unequivocal component that educators can focus on when expecting to hoist learning (Norton, 2000). The essential establishment to accomplish the greatest outcome in learning is through the motivation of every student to comprehend the main role of their learning. Besides, students' motivation is impacted by a few extraneous elements, like parental involvement in their learning. Appropriate involvement by parents in assisting their children is fundamental in forming their motivation to advance well in their learning.

Motivation has been characterized as a complete reason or direction in terms of second language learning (Gardner and Lambert, 1972). Various variables add to each motivation possessed by all students, and those variables can begin from themselves or their environmental factors. Developing their motivation in language learning is vital in supporting them in their performance in their language learning. One of the critical elements to impact their motivation is their parents. It is a foremost need for students, particularly the young ones to get sufficient assistance from their parents since they are not proficient yet in being independent and depend more on the involvement of parents during their language learning.

Connections between parental involvement and students' purposes suggest that students' purposes outgrow a family-wide orientation, and, therefore, the level of ability 
which the students achieve in a second language will be subject to the attitudinal environment in the home. (Gardner, 1975, p. 239). The involvement of parents to engage in their children's language learning influences the internal motivation and mentality of every student to perform well in their language learning. When the students gain adequate support from their parents, they can reinforce their inward motivation to accomplish the positive objective in language learning.

\section{Zone Proximal Development}

The Zone of Proximal Development (ZPD) is the most comprehensively known and used of Vygotsky's thoughts. There are various things that a child may see others around them performing, which no proportion of teaching or endeavoring will allow them to attempt to duplicate. There is an extent of intellectual abilities, in any case, between those which, from one perspective, the child can overcome even without assistance, on the other side, the children cannot regulate if not assisted. Parental involvement occupies an essential part in enabling students to resolve obstacles in their vocabulary learning.

Sufficient assistance and support from parents can elevate their children's ability to achieve expected learning outcomes. The reach in these two cutoff points is known as the ZPD, inside which the children can manage the activity at whatever point assisted. As shown by Vygotsky these are the 7 limits that exist in the youngsters' range and children can be educated. If two kids are chosen to be at a comparable level as what they can do autonomously, one child can achieve more than the other when assisted, it shows the educators the additional ability of the child to their development.

\section{Studies on Parental Involvement in Foreign Language Learning}

Prior studies like Alawawda and Razi (2020) examined the relationship between parents' education and their contribution to Iranian ESP students' self-guideline and language learning performance. The participants who took part in this study were 460 Iranian college students chosen out of 575 participants. Ryan's (2005) Parental Involvement Questionnaire, alongside the changed version of Tseng et al. (2006) selfadministrative scale were applied. To examine the information, Structural Equation Modeling was put to impact utilizing the AMOS program. The results of the attested model portraying parents' education levels, involvement, as well as students' selfguideline and language performance are following the obtained information. The results of the Structural Equation Model depicted that parents' education levels successfully and generally related to the students' self-guideline. Also, the outcomes of path analysis depicted a positive and imperative relationship between parents' education and students' achievement in their language learning.

Wadho et.al (2016) led an investigation at the university level in Kambar Shahdadkot and investigated the imperative effect of parents and instructors on L2 learning. The exploration carried out a quantitative way to deal with the research questions. The overview was completed, and all data were inferred utilizing a 
questionnaire. This research uncovered those students were extraordinarily influenced by parents and instructors in their learning progress. Most students learn the English language identified with the commitment they need to satisfy to show regard to their parents and instructors. The parents and instructors show a positive reaction towards the English language which influences L2 students' motivation and choices surprisingly. The study likewise recognized that dominant L2 students learn the English language by considering the rewards offered to them whenever they have achieved a specific improvement in their learning. Additionally, the uplifting attitude is shown by instructors likewise remains another factor to influence students' motivation. It was additionally discovered that inadequate input from educators amounts to a factor that demotivates the L2 students. This investigation states that the effective approach is a conclusive segment in L2 motivation and adds to positive results for students.

Hosseinpour (2015) conducted a study investigating and assessing the imperative role of Iranian parents' involvement and demeanor concerning their children's foreign language

learning. The involvement level and their demeanor were assessed. Additionally, this examination proposed to investigate the impact of some different factors like parents' gender, English ability, income, and levels of education on the parents' involvement and attitude. A questionnaire was conveyed to 140 parents to sort out the recurrence of their involvement and demeanor toward their children's language learning. Concerning the normal curve and the $Z$ score, the parents were divided into two groups, one with the more elevated level of involvement and more positive demeanor and the other with the lower level of involvement and less positive demeanor. By using a standard final accomplishment test of the coursebook among 70 primary school students in 3rd grade, as well as an Independent T-test analysis, the implications of parents' involvement and demeanor were examined. The outcomes of this investigation uncovered that those parents who have a high degree of involvement and demeanor toward their children's English language programs added to a more elevated level of performance in their children's language learning. Moreover, different outcomes highlighted that there is a great difference between the parents' capacity to use English, economy level, educational background, as well as their involvement levels and demeanor which additionally affected the performance of their children.

\section{METHODOLOGY}

The general design of this study is quantitative correlational research that investigated the relationship between parental involvement and students' achievement in their vocabulary learning. This study utilized descriptive statistics and the inferential statistics technique. A quantitative method was utilized in this study since it proposed to address the research questions identified with the connection between one variable (parental involvement) and another variable (vocabulary achievement). 
The primary source of information in this research was derived from a multilingual primary school in Malang city. This elementary school is one of the elementary schools in Malang city that teaches the local language, Indonesian, Chinese, and English to each one of the students. All participants participating in this study were 30 parents and 30 elementary students (ages 9 - 12 years of age); going to grades fourth - sixth. The participants were selected by considering the English teacher's assessments in several aspects of language learning (speaking, reading, listening, and writing).

\section{Instrument and data collection}

This study applied a Parental Involvement Questionnaire to acquire data concerning parental involvement toward their children's vocabulary achievement. This questionnaire involved two different parts, the first segment centered around parental involvement, and the second part focused on the attitude to which the parents provided to enhance their children's achievement. This questionnaire was an adjusted version of the one used by Hosseinpour et.al (2015). All participants were required to complete the questionnaire and submit the responses to the researcher

In regard to students' vocabulary achievement, the data in this study were obtained through teacher's assessments reflecting vocabulary achievement performance. The researcher utilized the assessments run by the English teacher that covered all the students' scores, especially vocabulary learning.

\section{Data Analysis}

The data were computed using SPSS software .25. The questionnaire was analyzed in terms of the reliability of the two instruments and statistical measurements. The results of the questionnaire uncovered the levels of parental involvement in their children's vocabulary achievement. Both parental involvement and attitudes were consolidated as one part that filled in as an estimation of the student's achievement. Concerning the general information from questionnaire and vocabulary achievement scores, descriptive statistics was utilized to portray the general scores for both questionnaire responses and students' vocabulary achievement scores by the entire participants. To address research question 1, Pearson's product-moment correlation was utilized to evaluate the connection between parental involvement and the teacher's assessment of students' performance. Meanwhile, to address research question 2, the outcomes of the questionnaire were parted into two assorted parts which classified the parents as bachelor and non-bachelor classifications. Then, at that point, an independent t-test was presented to analyze the levels of education, and their involvement in the two groups are statistically different. 


\section{RESULTS \& DISCUSSION}

\section{Results}

Parental Perspectives Regarding Their Involvement and Students' Vocabulary Achievement

Table 4.1 Mean and standard deviation for items

\begin{tabular}{|c|c|c|c|}
\hline & Statements & Mean & SD \\
\hline \multicolumn{4}{|c|}{ o. } \\
\hline & My child talks positively at home about foreign language class. & 4,27 & 0.58 \\
\hline & My child's comments are positive about foreign language learning. & 4,23 & 0.68 \\
\hline & My child feels successful in the foreign language class. & 4,13 & 0.63 \\
\hline & My child likes the foreign language. & 4,27 & 0.69 \\
\hline & My child likes the foreign language teacher. & 4,50 & 0.73 \\
\hline & $\begin{array}{l}\text { I am receiving enough information about the foreign language program at the } \\
\text { school. }\end{array}$ & 4,00 & 0.53 \\
\hline & I have seen my child performing in a foreign language school program. & 4,07 & 0.78 \\
\hline & I have visited my child's foreign language classroom. & 3,80 & 0.66 \\
\hline & $\begin{array}{l}\text { My child brings home useful foreign language worksheets, song handouts, or } \\
\text { information. }\end{array}$ & 4,07 & 0.45 \\
\hline & My child uses a foreign language frequently at home. & 3,43 & 0.86 \\
\hline 0 & & & \\
\hline & I am in favor of teaching a foreign language to children. & 4,20 & 0.89 \\
\hline 2 & $\begin{array}{l}\text { I feel that studying a foreign language has not jeopardized my child's progress } \\
\text { in other subject areas, such as math or reading }\end{array}$ & 4,57 & 0.50 \\
\hline 3 & $\begin{array}{l}\text { My child is benefiting from the elementary foreign language program at our } \\
\text { school. }\end{array}$ & 4,57 & 0.57 \\
\hline & Overall & 4,16 & 0.65 \\
\hline
\end{tabular}

Table 4.1 above depicted descriptive statistics in regards to the mean and standard deviation of parents' reactions to a survey about parental involvement in students' vocabulary achievement. The general scores of $4.16(S D=0.65)$ exhibited that parental involvement was exceptionally high. Seeing more detail on the items, the highest responses were items 12 (4.57), 13 (4.57), and 5 (4.50).

Responding to the research question of this study regarding the relationship of parental involvement and their children's vocabulary achievement, Pearson correlation 
was computed and found that there was a significant correlation between parental involvement and their children's vocabulary achievement, at $r=.39, p=.034$. This demonstrated that the relationship between parental involvement and children's vocabulary achievement was evident and confirmed, suggesting that the more parents get involved in supporting their children, the more proficient their children in terms of vocabulary achievement. This study is also interested in looking at the patterns of parental involvement as affected by parents' educational backgrounds.

The Role of Parents'Educational Background and Their Levels of Involvement in Their Children's Vocabulary Achievement

The second purpose of this study was to look at the role of parents' levels of education as classified as a bachelor $(n=20)$ and non-bachelor degree $(n=10)$ on the pattern of the involvement level in assisting their children's vocabulary achievement.

Table 4.2 Descriptive statistics of parents' educational background and the level of involvement.

\begin{tabular}{llcclcll}
\hline Status & $\mathrm{N}$ & Mean & SD & \multicolumn{2}{l}{$\begin{array}{l}\text { 95\% Confidence Interval } \\
\text { for Mean } \\
\text { Lower } \\
\text { Bound }\end{array}$} & $\begin{array}{l}\text { Minimu } \\
\mathrm{m}\end{array}$ & $\begin{array}{l}\text { Maxim } \\
\text { Bound }\end{array}$ \\
& & & & & & & \\
\hline $\begin{array}{l}\text { Non- } \\
\text { bachelor }\end{array}$ & 10 & 3.90 & 3.36 & 3.65 & 4.14 & 3.4 & 4.5 \\
$\begin{array}{l}\text { Bachelor } \\
\text { Total }\end{array}$ & 20 & 4.30 & 4.36 & 4.09 & 4.50 & 3.2 & 4.9 \\
\hline
\end{tabular}

Table 4.2 above uncovered the evidence that the parent's levels of education occupied a part in presenting guidance for their children, exhibiting the fact that parents with bachelor degrees showed more parental guidance or involvement in their children's vocabulary achievement $(M=4.3, S D=4.36)$ than parents with non-bachelor degree or lower schooling levels ( $M=3.9, S D=3.36)$. In different words, non-bachelor parents showed a lower level of involvement to improve their children's achievement in vocabulary learning. Meanwhile, bachelor parents got included all the more effectively in providing support for their children's vocabulary achievement.

An independent t-test was computed to see whether the two groups were statistically different or not. The study found that there was the level of involvement by parents with a bachelor's degree $(M=4.3, S D=4.36)$ was significantly higher than such of parents with a non-bachelor degree $(M=3.9, S D=3.36)$; $t(28)=-2.54, p=0.017$. Moreover, this study confirmed the fact that children with bachelor degree parents showed a higher 
vocabulary achievement than children with non-bachelor degree parents as shown in Table 4.3.

\begin{tabular}{|c|c|c|c|c|}
\hline & Education & $\mathrm{N}$ & Mean & Std. Deviation \\
\hline \multirow{2}{*}{ Vocab } & Non-bachelor & 10 & 86.00 & 6.342 \\
\hline & Bachelor & 20 & 90.60 & 5.144 \\
\hline
\end{tabular}

The information above portrayed that the normal score of students with parents having bachelor's degrees showed higher achievement $(M=91)$ than students whose parents with a non-bachelor degree with $(M=86)$. Concerning the data above, it can be reasoned that parents' educational background can improve understudies' accomplishment in their foreign language learning.

An independent t-test was computed to see whether the two groups' vocabulary scores were statistically different or not. The study found that there was children's vocabulary achievement by parents with a bachelor degree $(M=91, S D=5.14)$ was significantly higher than children with parents with non-bachelor degree $(M=86, S D=6.34)$; $t(28)=-2.14, p=0.041$.

\section{Discussion}

Upholding for the principal finding of this study concerning the basic role of parents in improving their children's vocabulary achievement, parents should comprehend their effect on their children's advancement. Their choices and involvement are fundamental for the improvement of their children's capacities which is also a deciding element to accomplish incredible learning results. Parents need to understand that every involvement they participate in decides their children's accomplishments. Vygotsky declared that children's intellectual capacities are created through connection with their environmental factors and everyone around them whom they alluded to as 'significant others' (Turuk, 2008). Parents need to guarantee that their kids derive all the help they need to advance adequately in their language learning.

Parental involvement or guidance is equipped to suit the students' present phase of knowledge. Thus, students who experience more deterrents in the learning cycle will get more clues and help. When students appreciate reasonable and fitting methods of managing their hindrances, they can concoct a legitimate answer for discovering the appropriate response. Despite what is generally expected, when children do not receive sufficient help and involvement from their parents, they will in general debase in their learning process and become more averse to accomplish extraordinary results.

Marchman et al, (2017) guaranteed that the students who receive less assistance from their environment during their initial years are less inclined to determine strength 
in some basic abilities for language learning and in this way, perhaps a deficiency for ineffectual language and psychological outcomes, contrasted with children who obtain sufficient support during their initial learning. Parental involvement in their children's language learning can be viewed as two assorted parts that both possess critical jobs in deciding their children's accomplishments in their language learning.

The study by Gardner (1985) uncovered that there are two imperative roles that parents establish in their children's advancement to learn the second language. These roles allude to as "the active and passive roles". The active role identifies with the parents' encouragement and assistance for their children to gain proficiency in their second language, as well as to ensure persistent checking of their performances in the language learning. On the other hand, the passive role alludes to parents' demeanors focused on their second language environment. Parents should know about the basic parts of the two sorts of encouragement and support above to expand their children's performance and guarantee the children receive the care and attention they require.

Based on the outcomes of this research, they reveal that parents' educational background is likewise a deciding component that impacts students in vocabulary achievement in their foreign language learning. Parents who have a qualified educational background and have adequate knowledge of the target language provide more assistance and guidance to heighten their children's capacities to perform and accomplish incredible results in their language learning.

It has been portrayed in the literature that the creating process of children's vocabulary exceptionally depends on the parents' language capacities. For instance, Huttenlocher et al, (1991) surveyed a few families and noticed the connection between the parents and their children as far as language learning. The study revealed that the level of parents' language capacities decides their children's achievement in language learning, while different studies uncovered that the assortment and intricacy of the parents' language information decidedly influence their children's vocabulary learning. In this way, a decent connection among parents and children is basic to help them in seeking after a great vocabulary achievement.

Additionally, Vygotsky explained the basic part of environmental communication in shaping a child's cognizance (Turuk, 2008). Having parents with high levels of education and language capacities is a benefit for students to obtain all the guidance and involvement to hoist their accomplishment. On the opposite side, having restricted language capacity and education deficiencies is one of the variables that thwart parents to get included altogether in their children's language learning. In this manner, it results in their children's inadequacy to receive the best possible results.

Moreover, regarding the connection between parental involvement on academic achievement and children's motivation, Wigfield et al. (2007 as referred to in Butler, 2013) found a necessary connection between parents' degrees of education with children's academic performance. The discoveries uncovered that the more qualified the education 
of their parents, the more probable it for their children to prevail in their language learning. By the past discoveries, Zou and Zhang (2011) additionally depicted the fact that children's language learning was profoundly controlled by the educational background of their parents. It advocated that when children sense adequate help and involvement from parents, they are profoundly plausible to accomplish more prominent outcomes at school.

\section{CONCLUSION}

The primary aim of this study was to inspect the levels of parental involvement in hoisting their children's performance in their vocabulary achievement in Malang city, Indonesia. The outcomes uncovered that parental involvement can be viewed as a compelling aspect in their children's accomplishments. The outcomes depicted that those students who received more involvement from their parents accomplished preferable outcomes over those with less positive involvement. This outcome came out as the appropriate response to the principal research question concerning the level of significance of parental involvement in their children's achievement. Additionally, the findings of this study also justified the outcomes of the previous research by Hosseinpour in 2015 concerning parental involvement toward their children's foreign language program at school. The outcomes also revealed the imperative role of parents in elevating their children's performance in their English program. The students who received more support from parents performed better than the students with a lack of support from parents. Moreover, the findings of this current study confirmed the crucial role of parental involvement in a slightly different area of language learning. Parents enact an important part in students' vocabulary achievement which is justified by the findings of this current research that students with sufficient parental involvement tend to achieve better outcomes compared to students with less parental involvement.

Concerning the results of this study, the response to the second question was additionally inferred. The relationship between parents' degrees of education and their involvement level was discovered as well which filled in as proof that students' capacity to accomplish an incredible result was affected by their parents' education. Furthermore, it also suggests that the higher their education, the more parents engage in working with their kids to accomplish a great result in their foreign language learning. Although the number uncovered that the connection is not significant, yet the score range legitimized that the degrees of education additionally involved an essential part in students' accomplishment.

\section{REFERENCES}

Alawawda, M., \& Razi, O. (2020). Parental involvement in early second language learning: The role of the immediate environment. Revista De Cercetare Si Interventie Sociala, 69, 23-48. Retrieved from https://search.proquest.com/scholarly- 
journals/parental-involvement-early-second-language/docview/2426792775/se2? accountid $=46437$

Al Harthy, S. R. (2020). Investigating Omani parental involvement in their children's English language learning (Order No. 27833197). Available from Publicly Available Content Database. (2404648660). Retrieved from https://search.proquest.com/dissertations-theses/investigating-omani-parentalinvolvement-their/docview/2404648660/se-2?accountid=46437

Alwasilah, A. C. (2013). Policy on foreign language education in Indonesia. International Journal of Education, 7(1), 1-19.

Atasheneh, N., \& Naeimi, M. (2015). Vocabulary learning through using mechanical techniques vocabulary learning strategy. Theory and Practice in Language Studies, 5(3), 541-548. doi:http://dx.doi.org/10.17507/tpls.0503.13

Barnes, J. A., Ginther, D. W., \& Cochran, S. W. (1989). Schema and purposes in reading comprehension and learning vocabulary from context. Reading Research and Instruction, 28, 16-28.

Birdsong, D. and Molis, M. (2001). On the evidence for maturational constraints in second language acquisition. Memory Lang., 44, 235-249. DOI:10.1006/jmla.2000.2750

Brown, H. D. (1997). Teaching by principles: An interactive approach to language pedagogy (3rd ed). Pearson Education.

Butler, Y. G. (2015). English language education among young learners in East Asia: A review of current research (2004-2014). Language Teaching, 48(3), 303-342. doi:http://dx.doi.org/10.1017/S0261444815000105

Butler, G. Y. (2013). Parental factors and early English education as a foreign language: A case study in Mainland China. Asia Pacific Education, Language Minorities and Migration (ELMM) Network Working Paper Series, 8. The University of Pennsylvania.

Butler, D., K. Urrutia, A. Buenger, N. Gonzalez, M. Hunt \& C. Eisenhart. (2010). A review of the current research on vocabulary instruction: A research synthesis.

Chang, K. L., Lin, S. E. \& Abdul Rashid, M. (2014). Benchmarking year five students' reading abilities. English Language Teaching, 7(5), 50-58.

Dawson and Phelan (2016) Language Files. Materials for an Introduction to Language and Linguistics (12th ed.). The Ohio State University Press

Fang, X., \& Perfetti, C. A. (2019). Learning new meanings for known words: Perturbation of original meanings and retention of new meanings. Memory \& Cognition, 47(1), 130-144. doi:http://dx.doi.org/10.3758/s13421-018-0855-z

Fateme, S. M. (2017). The effect of authentic problem-based vocabulary tasks on vocabulary learning of EFL learners. International Journal of Education \& Literacy Studies, 5(3), 35-40. doi:http://dx.doi.org/10.7575//aiac.ijels.v.5n.3p.35

Folse, K. S. (2004). The Underestimated Importance of Vocabulary in the Foreign Language

Classroom,

[Online]

Available: 
http://www.seasite.niu.edu/trans/articles/Underestimated\%20Importance\%20of \%20 ocab.htm (January 27, 2013).

Furneaux, C. L. 1999. Vocabulary Teaching. In Johnson, K. \& Johnson, H. Encyclopedic Dictionary of Applied Linguistics (pp. 367-369). Oxford: Blackwell.

Gardner, R. C. \& Lambert, W. E. (1972). Attitudes and motivation in second language learning. Newbury House.

Gardner, R. C. (1975). Attitudes and motivation: their role in second language acquisition. In Oller, J. W. \& Richards, J. C. (eds) Focus on the Learner: Pragmatic Perspectives for the Language Teacher. Newbury House.

Gardner, R. C. (1985). Social psychology and second language learning. Edward Arnold.

Gardner, R.C. (2001). "Integrative motivation and second language Acquisition" in Z. Dörnyei \& R.Schmidt (Eds.), Motivation and second language acquisition (Technical Report no.32) 422-459. Honolulu: University of Hawaii, Second Language Teaching and Curriculum Center.

Gardner, R.C. (2010). Motivation and second language acquisition: The Socio-Educational Model. Peter Lang Pub.

Han, T., Takkaç-Tulgar, A., \& Aybirdi, N. (2019). Factors causing demotivation in the EFL learning process and the strategies used by Turkish EFL learners to overcome their demotivation. Advances in Language and Literary Studies, 10(2), 56-65. doi:http://dx.doi.org/10.7575/aiac.alls.v.10n.2p.56

Hosseinpour, V., Sherkatolabbasi, M., \& Yarahmadi, M. (2015). The impact of parents' involvement in and attitude toward their Children's foreign language programs for learning English. International Journal of Applied Linguistics \& English Literature, 4(4), 175-185. doi:http://dx.doi.org/10.7575/aiac.ijalel.v.4n.4p.175

Huttenlocher, J., Haight, W., Bryk, A., Seltzer, M., \& Lyons, T. (1991). Early vocabulary

growth: relation to language input and gender. Developmental Psychology, 27 (2),

236. DOI: 10.1037/0012-1649.27.2.236

Inngam, P., \& Eamoraphan, S. (2014). A comparison of students' motivation for learning English as A foreign language in selected public and private schools in Bangkok. Scholar, 6(1) Retrieved from https://search.proquest.com/scholarlyjournals/comparison-students-motivation-learningenglish/docview/2384110137/se-2?accountid $=46437$

Krashen, S. (1989). We acquire vocabulary and spelling by reading: Additional evidence for the input hypothesis. The Modern Language Journal, 73, 440-464.

Marchman, V.A., Martínez, L.Z., Hurtado, N., Grüter, T., \& Fernald, A. (2017). Caregiver

talks to young Spanish-English bilinguals: comparing direct observation and parentreport measures of dual-language exposure. Developmental Science, 20(1), e12425.

DOI: $10.1111 /$ desc.12425. 
Nation, I. S. P. (2001). Learning vocabulary in another language. Cambridge University Press.

Norton, B., \& Syed, Z. (2003). TESOL in the Gulf: the sociocultural context of English language teaching in the Gulf. TESOL Quarterly, 37(2), 337-341.doi: $10.2307 / 3588508$

Schmitt, N., Jiang, X., \& Grabe, W. (2006). The percentage of words known in a text and reading comprehension. The Modern Language Journal, 95(i), 26-43. DOI: 10.1111/j.1540 4781.2011.01146.x

Schmitt, N. (1997). Vocabulary learning strategies. In N. Schmitt \& M. McCarthy (Eds.), Vocabulary: Description, acquisition and pedagogy (pp. 199-227). Cambridge, UK: Cambridge University Press.

Turuk, M.C. (2008). The relevance and implications of Vygotsky's sociocultural theory in the second language classroom. ARECLS, 5, 244-262.

Vygotsky, L. S. (1999).The collected works of L. S. Vygotsky. Vol. 6: Scientific legacy. New York, NY:Plenum Press.

Vygotsky, L. S. (1986).Thought and language. MITPress

Wadho, S., Memon, S., \& Rafique, A. M. (2016). Motivation to learn English language: A survey on parents' \& teachers' influence on L2 learners in sindh, Pakistan. Advances in Language and Literary Studies, 7(4), 253-258. Retrieved from https://search.proquest.com/scholarly-journals/motivation-learn-englishlanguage-survey-on/docview/2188085737/se-2?accountid=46437

Walker, D., Greenwood, C., Hart, B., \& Carta, J. (1994). Prediction of school outcomes based on early language production and socioeconomic factors. Child Development, 65, 606-621. https://doi.org/10.2307/1131404

Wang, L. and H. Chang, (2011). Improve oral training: The method of innovation assessment on English speaking performance. Int. J. Distance Educ. Technol., 9, 56-72. DOI: 10.4018/jdet.2011070105

Wehmeier, S., McIntosh, C., Turnbull, J., \& Ashby, M. (Eds.). 2005. Oxford Advanced Learner s Dictionary of Current English. Oxford University Press.

Yulianti, K., Denessen, E., \& Droop, M. (2018). The effects of parental involvement on children's education: A study in elementary schools in Indonesia. International Journal About Parents in Education, 10(1), 14-32.

Zhang, J., \& Lynch, R. (2017). The relationship between primary 5 and 6 students' perceptions of parental encouragement and their academic achievement in mandarin learning at an international school, Bangkok. Scholar, 9(2), 243. Retrieved from https://search.proquest.com/scholarly-journals/relationshipbetween-primary-5-6-students/docview/2384108756/se-2?accountid=46437

Zou, W. C., \& Zhang, S. L.(2011). Family background and English learning at a compulsory stage in Shanghai. In A. Feng (Ed.), English language education across Greater China (pp. 189-211). Bristol: Multilingual Matters. 
Zhang, X. (2013). The 'I Don't Know' option in the Vocabulary Size Test. TESOL Quarterly, $47,790-811$. 